\title{
Hemarthrosis in hemoglobin $\mathrm{E}$ beta thalassemia: a rare clinical scenario
}

\author{
Malini Garg, Prakas K. Mandal*, Prakash S. Shekhawat, Tuphan K. Dolai
}

Department of Haematology, Nil Ratan Sircar Medical College, Kolkata, West Bengal, India

Received: 30 July 2020

Accepted: 01 September 2020

*Correspondence:

Dr. Prakas K. Mandal,

E-mail: pkm.hem@gmail.com

Copyright: (c) the author(s), publisher and licensee Medip Academy. This is an open-access article distributed under the terms of the Creative Commons Attribution Non-Commercial License, which permits unrestricted non-commercial use, distribution, and reproduction in any medium, provided the original work is properly cited.

\section{ABSTRACT}

Hemorrhagic joint effusions are rarely seen in patients with haemoglobinopathies. Joint effusions often develop in association with deferiprone-related arthropathy in beta thalassaemia patients. Here we report a very rare case of bilateral knee and hip joint effusions in a case of hemoglobin $\mathrm{E}(\mathrm{HbE})$ beta thalassemia patient.

Keywords: HbE beta thalassemia, Hemarthrosis, Rare presentation

\section{INTRODUCTION}

Joint effusions can rarely be seen in patients with haemoglobinopathies, especially in sickle cell anemia (SCA) patients; symptomatic joint effusions have shown vascular occlusion. ${ }^{1}$ Joint effusions often develop in association with deferiprone-related arthropathy in beta thalassaemia patients. ${ }^{2,3}$ Joint effusions as such in thalassemia patients are rarely reported. Here we report a very rare case of bilateral knee and hip joint effusions in a case of hemoglobin $\mathrm{E}(\mathrm{HbE})$ beta thalassemia patient.

\section{CASE REPORT}

A 32 year old patient, a known case of $\mathrm{HbE}$ beta thalassemia with type II diabetes mellitus and hypothyroidism presented in hematology department with painful swelling of both knee joints and pain in both hip joints since one month. The swelling was insidious in onset and gradually progressive and was not associated with morning stiffness. There was no history of antecedent trauma. Pain increased on walking or prolonged standing. No history of fever associated with it. He was diagnosed as a case of $\mathrm{HbE}$ beta thalassemia at 5 years of age; was transfusion dependent since then. He used to require 3 units of packed red cell per month for survival; splenectomised at 18 years of age. Following splenectomy, his transfusion requirement got reduced to one unit of packed red cell every 40-60 days. By occupation, he is a daily wage worker and his occupation did not involve any strenuous muscular activity. There was no similar history of joint effusions in any of his family members. He was on hydroxyurea, deferasirox therapy and folic acid and calcium supplementation.

On examination, he was poorly built and poorly nourished individual with moderate pallor. He had characteristic thalassemic facies, mild hepatomegaly and an old healed scar of splenectomy. Local examination of both the knee joints and hip joints revealed moderate effusions. They were warm to touch and were tender. There was restriction in mobility of both the joints due to pain. Examination of the other joints was normal. Systemic clinical examination did not reveal any significant abnormality. Complete haemogram showed $\mathrm{Hb} 72 \mathrm{~g} / \mathrm{l}$, peripheral smear revealed $17 \%$ nucleated red blood cells (RBCs), corrected total leukocyte count of 10.6 X 103 cells/ $\mu \mathrm{L}$ with $69 \%$ neutrophils, $26 \%$ lymphocytes, platelet count was $2.0 \mathrm{x}$ 106 cells $/ \mu \mathrm{L}$. RBCs were microcytic hypochromic with moderate anisocytosis. Viral markers were negative. Serum C-reactive protein (CRP) was $89.4 \mathrm{mg} / \mathrm{l}$, ferritin was $>1500 \mathrm{ng} / \mathrm{ml}$. Serum calcium was $9.1 \mathrm{mg} / \mathrm{dl}$, vitamin D3 level was $33.60 \mathrm{ng} / \mathrm{ml}$ and normal rheumatoid factor (RA) factor $(10 \mathrm{IU} / \mathrm{ml})$. Prothrombin time, activated partial thromboplastin time (aPTT) and fibrinogen were within normal limits. Blood culture showed no growth; urine routine tests, liver function tests, urea, creatinine, 
uric acid and lactate dehydrogenase (LDH) were within normal limits. Straight x-ray bilateral knee joint revealed increased joint space with intact articular cartilage (Figure $1 \mathrm{a}$ and $\mathrm{b}$ ). Ultrasonography of knee joints revealed mild intraarticular effusions. Magnetic resonance imaging (MRI) scan of both hip joints showed diffusely altered marrow signal intensity involving visualized part of femurs, iliac bones and acetabulum with hypointense lesions- suggestive of hemosiderin deposition with diffuse edema of pelvic floor muscles and mild bilateral intraarticular effusion. The articular cartilages were normal (Figure 2a and b). He was started on antibiotics in view of post splenectomy status, poorly controlled diabetes and increased risk of encapsulated bacterial infections. The pain got relieved with supportive care and antibiotics and effusion got reduced. He is continuing regular follow up at hematology out-patient department (OPD) and taking hydroxyurea, deferasirox, folic acid and calcium as before.
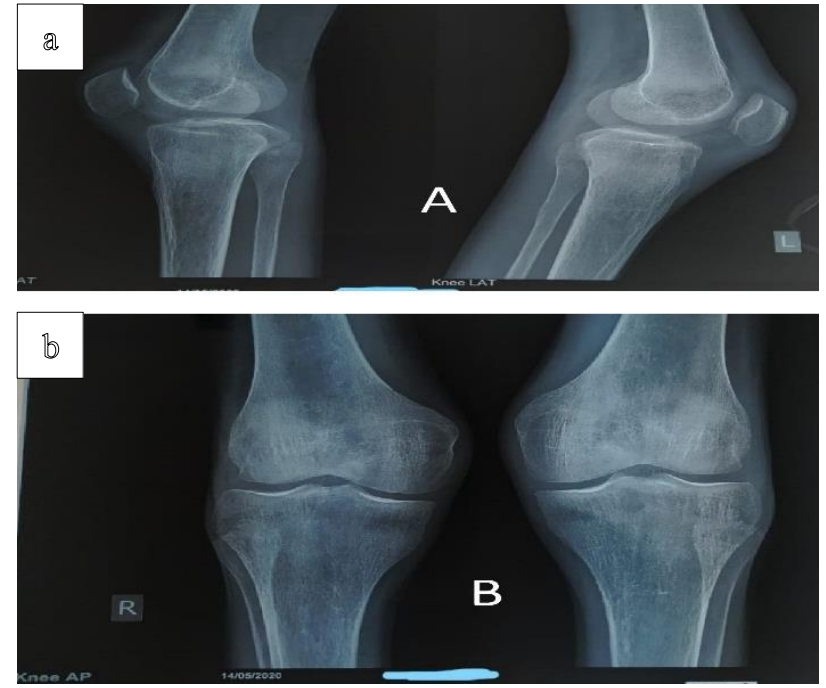

Figure 1: Straight x-ray bilateral knee joint revealed increased joint space with intact articular cartilage (a) lateral view; (b) anteroposterior view.
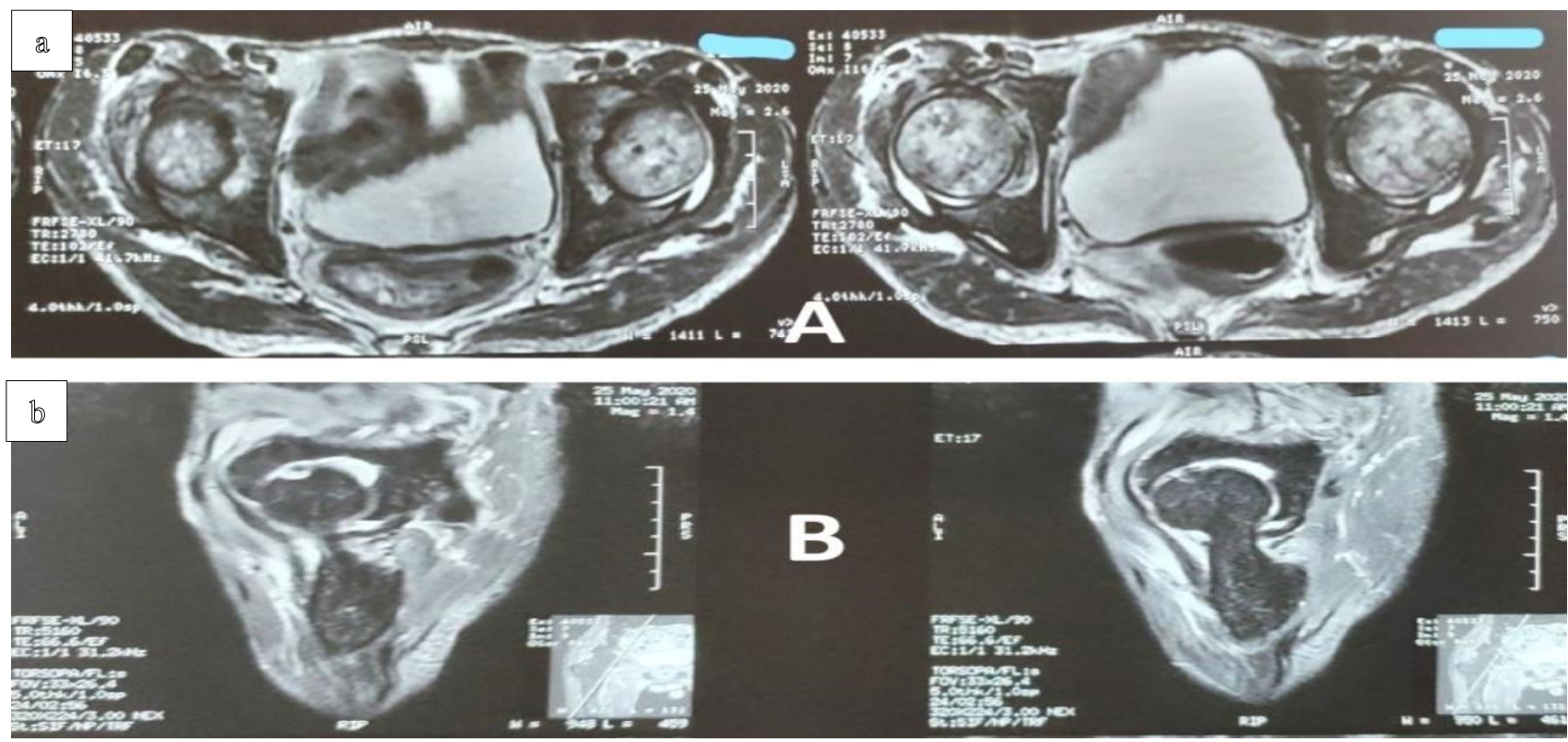

Figure 2: MRI scan of both hip joints showing effusion with hemosiderin deposition (hypointense signal) and normal articular cartilage (a) coronal section, and (b) sagittal section.

\section{DISCUSSION}

We describe a case of $\mathrm{HbE}$ beta thalassemia with bilateral knee and hip joint effusions with hemosiderin deposition. Even after thorough research, we didn't find any similar case report in $\mathrm{HbE}$ beta thalassemia patient. However, rare cases of beta thalassemia major with joint effusions have been reported. ${ }^{3}$ Crout et al had described a case of sickle beta-thalassaemia presenting with symptomatic joint effusions. ${ }^{1}$ The patient presented with history of recurrent polyarthralgias and myalgias, in addition to intermittent swelling of elbows and knees. Knee effusions were not associated with warmth or erythema; synovial fluid analysis showed non-inflammatory effusion. Chand et al described MRI findings in a case of deferiprone-induced arthropathy in beta thalassemia major. ${ }^{3}$ The symptoms developed 4 years after starting deferiprone therapy.

The present patient never received deferioxamine or deferiprone earlier; could it be due to deferasirox? Joint effusions per se or as a complication of deferasirox therapy in thalassemia patients especially in $\mathrm{HbE}$ beta thalassemia is not reported in the literature. Our patient had inflammatory effusion secondary to infective etiology which was supported by raised CRP and response to antibiotic therapy. He also had iron deposition in the joint space, which was supported by iron overload status. Joint effusions with inflammatory cause were supported by his 
post splenectomy status, poorly controlled diabetes and increased risk of encapsulated bacterial infections in post splenectomy patients.

\section{CONCLUSION}

Joint effusions is very rare but a disabling complication, that can also very rarely be seen in $\mathrm{Hb} \mathrm{E}$ beta thalassemia patients and must be kept in mind while attending to splenectomised thalassemic patient.

Funding: No funding sources

Conflict of interest: None declared

Ethical approval: Not required

\section{REFERENCES}

1. Crout JE, McKenna CH, Petitt RM. Symptomatic joint effusions in sickle cell-beta-thalassemia disease. Report of a case. JAMA. 1976;235(17):1878-9.

2. Kellenberger CJ, Schmugge M, Saurenmann T, Gennaro LD, Eber SW, Willi UV, et al. Radiographic and MRI features of Deferiprone-related arthropathy of the knees in patients with beta thalassemia. Am J Roentgenol 2004;183:989-94.

3. Chand G, Chowdhury V, Manchanda A, Singh S. Deferiprone-induced arthropathy in thalassemia: MRI findings in a case. Indian J Radiol Imaging. 2009;19(2):155-7.

Cite this article as: Garg M, Mandal PK, Shekhawat PS, Dolai TK. Hemarthrosis in hemoglobin E beta thalassemia: a rare clinical scenario. Int J Adv Med 2020;7:1582-4. 